\title{
Level of zinc in maize seeds and maize growing soils of central Mecha, Amhara National Regional State of Ethiopia
}

\author{
Girma Kibatu*, Taju Ahmed, Minalu Shawl and Liboro Hundito \\ *Bahir Dar University, College of Science, Inorganic, Coordination and Biological Inorganic Chemistry, Tel. \\ +251912159179 , P.O.Box 79, Bahir Dar, Ethiopia
}

\begin{abstract}
Ethiopia is one of the world countries with reported zinc deficiency or high probability of zinc deficiency. Zinc deficiency is an important soil constraint to crop production, food quality and human health. The aim of this study was to evaluate the zinc concentration of different cultivars of maize seeds and soil samples in central Mecha area using a laboratory analysis to establish whether the roles and effects of zinc in crop productivity and quality in the area could be significant due to plant factors (e.g. cultivar) or changes in soil nutrient zinc concentration or both. Thirty representative soil samples from seven kebeles of the central Mecha and six genotypes of maize grains (Bako Hybrid-540, Bako Hybrid-543, Bako Hybrid-660, Pioneer Hybrid-3253, Melkassa Hybrid-2, and Melkassa Hybrid-4) available in the region for farmers archived by Ethiopian Seed Enterprise (ESE) were collected and analyzed in the laboratory. Zinc levels were determined by FAAS using wet digestion and dilute acid extraction methods. The mean $\mathrm{pH}(\mathrm{KCl})$ value of the soils indicated the samples studied are acidic $(\mathrm{pH}=4.60)$. The means and ranges of concentrations of total zinc using strong acids wet digestion and available $\mathrm{HCl}$-extractable zinc in soils ( $\mathrm{mg} \mathrm{Kg}^{-1} \mathrm{DW}$ ) were $50.49 \mathrm{mg} \mathrm{Kg}^{-1}\left(44.80\right.$ to $65.22 \mathrm{mg} \mathrm{Kg}^{-1}$ ) and $2.95 \mathrm{mg}$ $\mathrm{Kg}^{-1}$ (1.76 to $\left.4.94 \mathrm{mg} \mathrm{Kg}^{-1}\right)$, respectively. ANOVA analysis revealed significant differences $(\mathrm{P}<0.05)$ between maize varieties in zinc levels. There was significant genetic variability in the level of zinc between the maize cultivars from $16.18 \mathrm{mg} \mathrm{Kg}^{-1}$ for Bako Hybrid-540; $20.08 \mathrm{mg} \mathrm{Kg}^{-1}$ for Bako Hybride-660; $21.08 \mathrm{mg} \mathrm{Kg}^{-1}$ for Pioneer Hybrid-3253; $23.26 \mathrm{mg} \mathrm{Kg}{ }^{-1}$ for Bako Hybrid-543; $29.38 \mathrm{mg} \mathrm{Kg} \mathrm{Kg}^{-1}$ for Melkassa-2 to $32.52 \mathrm{mg} \mathrm{kg}^{-1}$ for Melkassa-4. Chemical analysis of composite soil samples indicated that inherent zinc level was on the borderline sufficiency to support good crop growth for now, however; the variations in the level of zinc among the different maize cultivars should be significant in limiting high and quality yield for consumption. Adequate zinc in soils and high zinc concentrations in seeds ensure agronomic and nutritional benefits resulting in high yield and nutritional quality crops.
\end{abstract}

Keywords: Crops, Micronutrients, Zinc deficiency, Soil acidity, Ethiopia

DOI: http://dx.doi.org/10.4314/ejst.v9i1.1

\section{INTRODUCTION}

Zinc $(\mathrm{Zn})$ is an essential micronutrient for plants, animals as well as for humans (Hotz and Brown, 2004). It is an essential trace element and a constituent of more than 300 metalloenzymes involved in major metabolic pathways in biological systems that support life. Thus, there is always an optimal concentration of this essential element required by organisms; above or below the optimal concentration, in which a toxic or deficiency state in the ecosystem is developed may compromise health, quality and productivity. A typical doseresponse curve for elements in crops is shown below (Figure 1) (Alloway et al., 2004).

The soil is the primary source of zinc for plants, animals and humans. The zinc mineral that is supplied through the food chain from the soil overlying the surficial lithosphere could be sufficient, deficient or excessive resulting into effects on health, quality and productivity of plants, animals and humans; mostly with hidden symptoms and sometimes with clear subclinical and clinical symptoms. The underline zinc deficiency in soils and crops as-

\footnotetext{
*Corresponding author: girmak@,bdu.edu.et

(C) This is an Open Access article distributed under the terms of the Creative Commons Attribution License (http://creativecommons.org/licenses/CC BY4.0).
} 


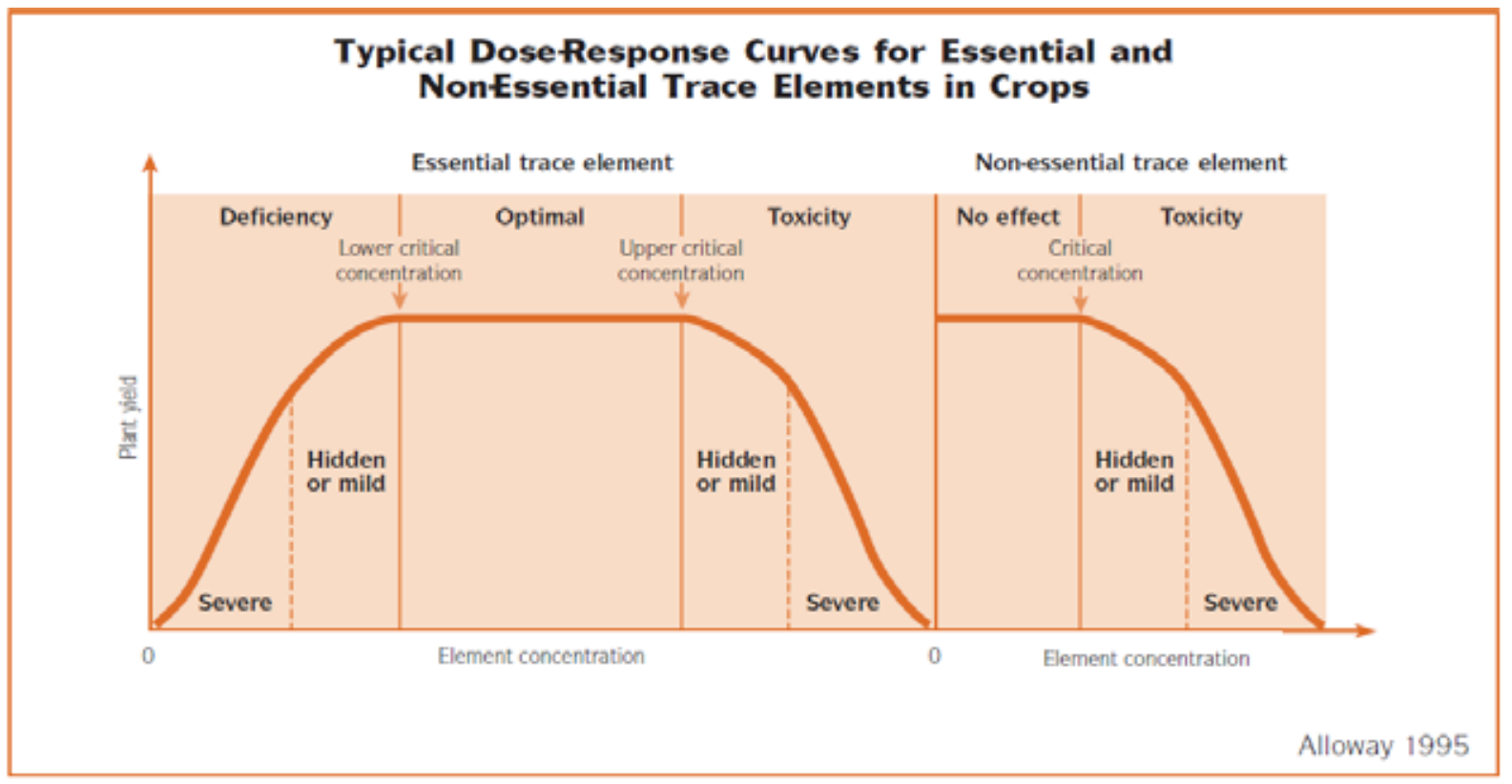

Figure 1. Typical dose-Response Curves for Essential and Non-Essential Trace Elements in crops.

sociated with soil infertility; yield loss, immaturity and chlorisis in plants is caused by several factors including low total zinc content in the soil, use of zinc inefficient crops, and high phosphate application among some others (Figure 2) (Cakmak, 2008).

Zinc deficiency in crop production is known in many parts of the world with deficient soils in their underlying agricultural soil. Agricultural productivity in Ethiopia is below the region average because of soil fertility problems due to nutrient depletion or unavailability. An earlier global project (initiated in 1974 by FAO) aimed to determine the status of soil micronutrients in agricultural systems

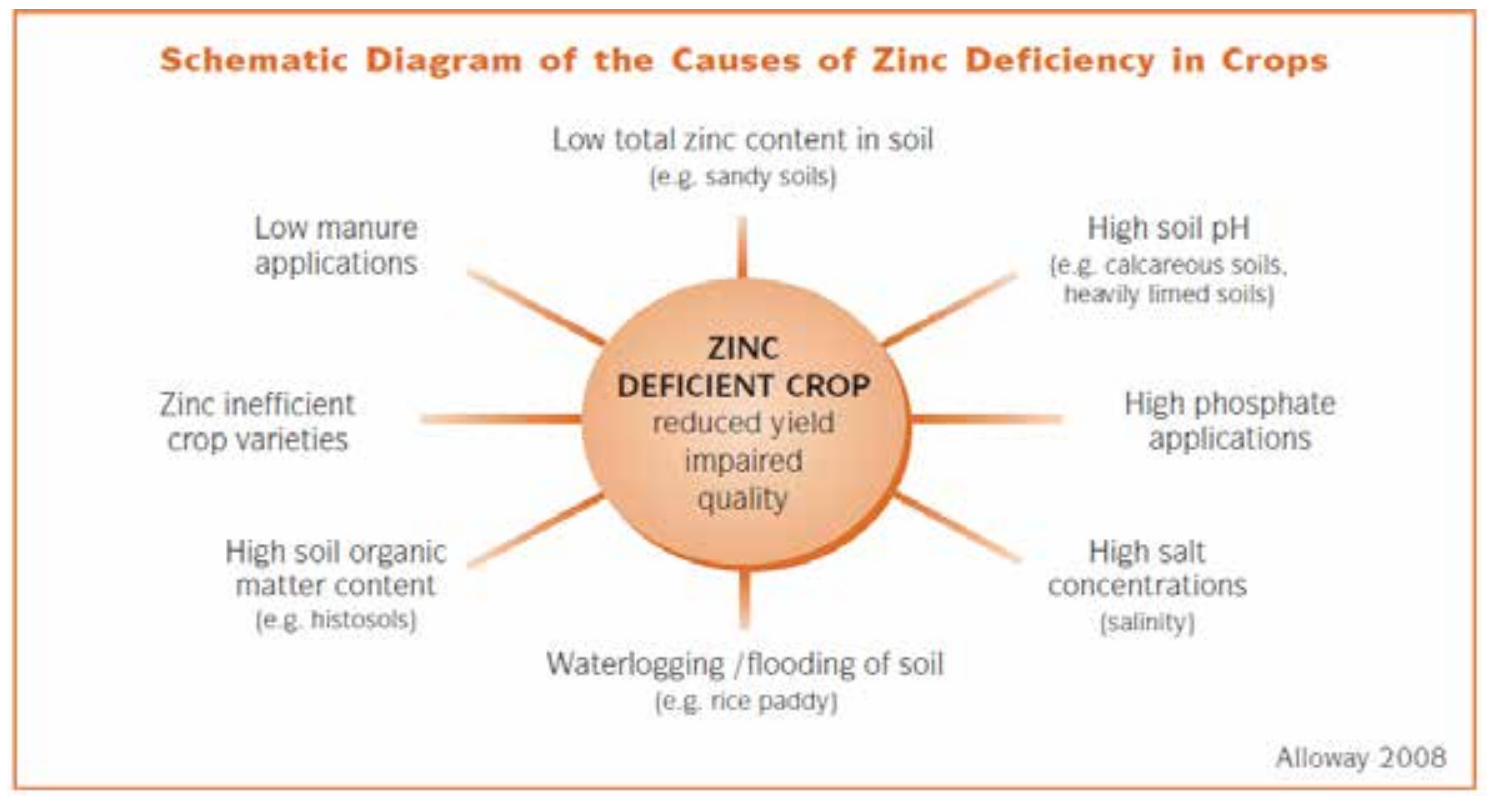

Figure 2. Schematic Diagram of the Causes of Zinc Deficiency in Crops. 
has showed low concentration products for iron and zinc deficiencies (Sillanpaa, 1990). In recent researches to assess the status of micronutrients in central highlands of Ethiopia the available $\mathrm{Zn}$ in Nitosols, Luvisols and Cambisols soils in Bale area were low (Teklu Baissa et al., 2005; Teklu Baissa et al., 2007; Asgelil Dibabae et al., 2007; Ashenafi Ali et al., 2010; Mesfin Kebede and Yifru Abera, 2013; Tuma Ayele et al., 2014).

According to a WHO report on the risk factors responsible for development of illnesses and diseases, $\mathrm{Zn}$ deficiency ranks 5 th among the 10 most important factors in developing countries. Zinc deficiency in animals and human beings due to the lack of $\mathrm{Zn}$ in their diet or unavailability for absorption is associated with cessation of growth, psychomotor delay, hypogonadism and suppression of both primary and secondary sexual characteristics. There are estimates that some two billion people worldwide are afflicted by Zn deficiency, and up to half of the population in developing countries are at risk of $\mathrm{Zn}$ deficiency (WHO, 2002).

Ethiopia is one of the world countries with reported zinc deficiency or high probability of zinc deficiency (Welch et al., 1991; Alloway et al., 2004). Zinc deficiency is an important soil constraint to crop production, food quality and human health. A study carried out in Ethiopia on existence of zinc deficiency showed that high prevalence of parental zinc deficiency exists and that it is one of the major contributing factors for high stunting rates in infants and young children in Ethiopia (Jemal Haider et al., 2005; Afework Kassu et al., 2008; Samson Gebremedhin et al., 2011). Zinc deficiencies are thus known in Ethiopian population particularly in rural and slum areas where people mainly depend on cereals as the main staple food and with little or no access to fruits and vegetables and animal products.

Generally, the distribution of zinc deficiency in the world correlates with the availability of Zinc in the biological ecosystem (Welch et al., 1991; Alloway et al., 2004). The regions with Zn-deficient soils are most of the time the regions where $\mathrm{Zn}$ deficiency in human beings is widespread, for example in India, Pakistan, China, Iran and Turkey (Yang et al., 2007). There are suggestions indicating that available $\mathrm{Zn}$ in the soils can be a limiting factor for crop production and zinc deficiency in the population who depend on $\mathrm{Zn}$ deficient soils. The main hazards that limit high yield crop production and access to quality food and micronutrients for human and livestock consumption in Ethiopia based their roots from soil fertility challenges including top soil erosion, organic matter, macro and micro nutrients depletion, acidity and an array of pests and diseases including African boll worm, grasshopper, maize stalk borer, aphids and root rot (Yihenew Gebreselassie, 2002; ATA, 2013). However, the empirical relationship between widespread Zn deficiency problem in Ethiopian population and soil concentrations and plant uptake has not been reported or diagnosed.

In this study availability of zinc in the soils of nitosols in central Mecha Kebeles in the south west maize livelihood area in Amhara and zinc accumulation in maize cultivar grains for seeds cropped in the area were diagnosed. The main objective of the study was to identify issues to improve the management of maize production in the study area with respect to yield and nutritional quality increment for human and livestock consumption in the region.

\section{MATERIALS AND METHODS}

\section{Description of the study area}

The South West Maize livelihood zone is one of the historically food secure areas in Amhara Region. It spreads across: West Gojam; Agew; and 
East Gojam. It is predominantly located in woina dega agro-ecology with some parts kola. The study area, Mecha woreda is located in this maize livelihood zone in the southwest Amhara Regional State in Ethiopia (Figure 3). The study sites cover seven central Kebeles around Merawi town, about $35 \mathrm{Km}$ south from Bahir Dar, the capital city of the Region. The seven Kebeles are Tagel Wodefit, Ambo Mesk, Inguti, Kudmi, Enamirt, Bachima and Enashenifalen. Together, they have a production area for maize (Zea mays L.) of more than 27,000 ha.

The region has a high crop production potential. However, agricultural productivity has not reached its potential so far and people living in the area who depend on staple foods from their agriculture have paradoxically witnessed micronutrient defi- ciencies (a hidden hunger) due to the lack of nutrient dense quality foods (Melaku Umeta, 2003).

\section{Research Methodology and Data Analysis}

Thirty representative soil samples from seven kebeles from central Mecha and six genotypes of maize grains ((three Bako Hybrids, BH-540, BH543 and BH-660); (a Pioneer Hybrid, PH-3253) and (two Melkassa Hybrids, $\mathrm{MH}-2$ and $\mathrm{MH}-4$ )) available in the region for farmers archived by Ethiopian Seed Enterprise (ESE) in Bahir Dar were collected and analysed for zinc levels during land preparation periods from February to June 2010. The randomly selected thirty half-hectare individual farm fields which were systematically chosen prior to the field visit using pre defined coordinates by a portable global positioning

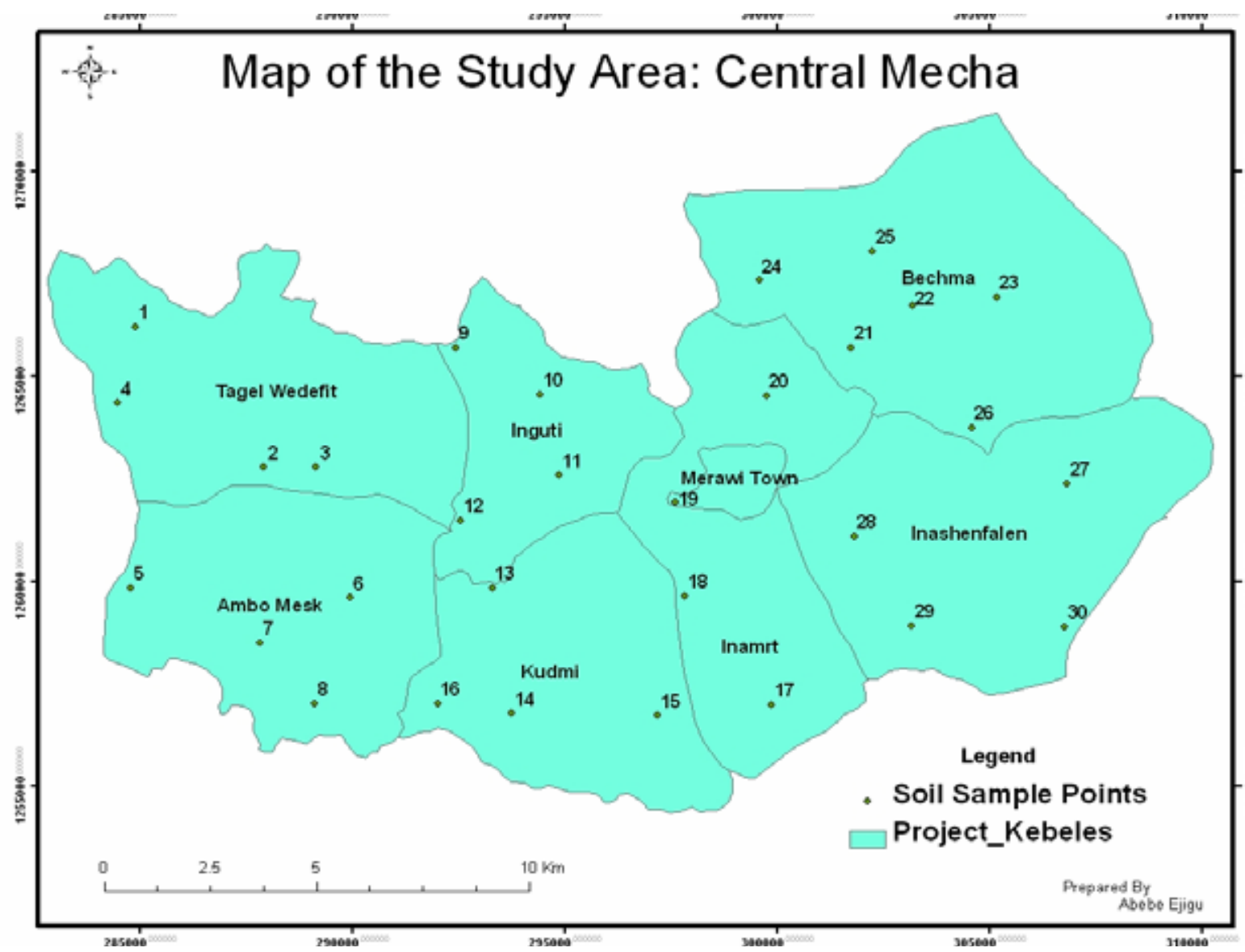

Figure 3. Map of the Central Mecha Kebeles and Farm Fields where thirty (1-30) Composite Soil Samples were collected. 
system (etrex Vista HCX Garmin, USA) with positional accuracy of a few meters into the nearest farm field. From each of this farm fields, six soil point samples of 0 to $20 \mathrm{~cm}$ depth were dug at different points in a zig-zag pattern inside the fields and mixed into one composite sample per field. In this way, thirty composite soil samples were collected from Enguti (4 fields), Enamirt (4 fields), Enashenfalen (4 fields), Kudmi (4 fields), Ambo Mesk (4 fields), Tagelwodefit (4 fields), Bachima (6 fields). Approximately $1 \mathrm{~kg}$ of each of the composite soil samples were packed in polythene bags and transported into laboratory; air-dried and passed through a $2 \mathrm{~mm}$ sieve and archived for standard laboratory analyses. About $100 \mathrm{~g}$ of each of the archived different cultivars of maize grain samples from regional Ethiopian Seed Enterprise archive in Bahir Dar were packed in polyethylene bag, transported, and rinsed briefly with deionized water, dried at $80{ }^{\circ} \mathrm{C}$, and ground into a powder with manual grinding in an agate pestle and mortar.

The soil $\mathrm{pH}$ was measured potentiometrically using a digital $\mathrm{pH}$ meter in a supernatant suspension of $1: 2.5$, soil: liquid ratio and the liquid were water and $1 \mathrm{M}$ of $\mathrm{KCl}$ using a method outlined by Van Reeuwijk (Van Reeuwijk, 1993). Oxidable organic carbon (OC) was measured using the method of Walkey and Black dichromate wet oxidation method (Walkey and Black, 1934). Approximately $10 \mathrm{~g}$ of composite soil samples from each field and gain samples from the ESE archive were further ground to $<0.15 \mathrm{~mm}$ in an agate ball mill.

The total zinc concentrations in the soil and grain samples were determined by a wet digestion method as described by Minaleshewa A (Minaleshewa et al., 2010) after about $0.5 \mathrm{~g}$ of the samples were digested with ultra pure concentrated $\mathrm{HCl}$ (36-38\%, Hopkins and Williams, UK), $\mathrm{HNO}_{3}$
(69-72\%, Spectrosol, BDH, UK) and hydrogen peroxide solutions (35\% v/v, Blulux, Laboratories (P) Ltd., India) in open vessels inside a fume hood. The extractable zinc concentrations from the soils were determined by approximately taking 0.5 $\mathrm{g}$ of composite soil samples from each field and extracting using $20 \mathrm{ml}$ of $0.01 \mathrm{M} \mathrm{HCl}$ extractant (soil: solution ratio1:5) according to Shituu, Brennan, Srivastava, and or Mclean and Langille (Mclean and Langille, 1976; Brennan et al., 1993; Srivastava et al., 1996; Shituu, 2013; Tayie et al., 2013). Distilled de-ionized water was used throughout the analysis.

Concentrations of $\mathrm{Zn}$ in the digests or extracts were determined by Flame Atomic Absorption Spectrometry (Buck Scientific Model 210 VGP, East Norwalk, USA) equipped with deuterium arc background correctors using air-acetylene flame (Lindsay and Norvell, 1978). All statistical analyses were performed by means of the software SPSS 11.5 (SPSS Inc. 2002) and Excel 2007 for Windows.

\section{Quality Assurance and Quality Control Methods}

To check the efficiency of the procedure in determining the total and phytoavailable zinc in soil and grain samples using Flame atomic absorption spectrometry triplicate measurements of the samples and measurements after appropriate stock solutions of zinc spiked on them were performed. The results of the percentage of recoveries for studied materials were all between 90 to $105 \%$. The detection limit of the instrument was determined to be as low as $0.5 \mu \mathrm{g} \mathrm{g}^{-1}$.

\section{RESULTS AND DISCUSSION}

\section{Properties of Studied Soils}

The soils in central Mecha woreda are largely developed on parent materials of volcanic origin 
predominantly basalt. In terms of topography, the zone is predominantly plain with some hills between 1500 and 2500 meters altitude (Yihenew Gebreselassie, 2002). The interrelationships between many soil-forming factors in years have resulted in the formation of an agriculturally important reddish brown soils which were classified Nitosols according to the FAO soil classification system. The soils are mostly red and moderately fertile. The reddish brown clay soils have deep profile that allow easy root penetration and combine good moisture retention with free drainage. All sampled soils were characterized by a medium to high clay content (about 30\% mean average that is ranging from 160 to $\left.560 \mathrm{~g} \mathrm{~kg}^{-1}\right)$. The soil OC content was generally low $(<1 \%)$, ranging from 3.57 to $6.2 \mathrm{~g} \mathrm{~kg}^{-1}$, which is typical for soils in the region. The $\mathrm{pH}(\mathrm{CaCl})$ (3.9 to 5.7) values of the soil samples studied in here indicated that about $4 \%$ of the soil samples were highly acidic ( $\mathrm{pH} 3-4), 76 \%$ of them were moderately acidic ( $\mathrm{pH} 4-5$ ) and only $20 \%$ of the sampled soils were slightly acidic (pH 5-6). Low organic matter, high phosphorus fixing capacity and acidity of the soil in the area has been previously identified as limiting factors for agricultural quality and productivity in the area (Yihenew Gebreselassie, 2002; ATA, 2013). Total annual rainfall is comparatively very high between 1713 and 1881 in the rainy season (Kiremt) which lasts from May to June and with a long-term mean of 1366 $\mathrm{mm}$ per annum. Temperature in the area varies between the mean annual maximum of $26{ }^{\circ} \mathrm{C}$ and mean annual minimum of $10{ }^{\circ} \mathrm{C}$.

\section{Total and Available Zinc Concentrations in Soils}

The total zinc content of a soil is largely dependent upon the geochemical composition of the weathering rock parent material on which the soil has developed (Kabata-Pendias and Pendias, 2001). However, in some cases, environmental pollution or the agricultural application of zinc-rich materials can mask the parent material's contribution. The average zinc content of rocks in the Earth's crust is $78 \mathrm{mg} \mathrm{Zn} \mathrm{kg}^{-1}$ and the average concentrations of zinc in the various types of rock which make up the Earth's crust show higher concentrations of zinc for the basic igneous rocks, such as basalts and for sedimentary rocks containing clay and shale basis. More silica-rich igneous rocks, such as granites, metamorphic rocks including gneiss, and sedimentary rocks including limestone and sandstone have much lower total zinc contents. These examples show a clear trend of low concentrations in sandy soils and higher zinc concentrations in soils with larger clay contents. Sandy soils all over the world are often found to have low, or deficient, zinc concentrations for crops. This is a consequence of both the higher zinc concentrations in clay and shale parent materials and also the greater ability of clay-rich soils to adsorb and retain zinc and other elements relative to soils with lower percentages of clay and higher percentages of sand (Alloway et al., 2004).

However, it is important to stress that in many parts of the world, soils tend to be very heterogeneous in their distribution, especially in areas affected by soil formation processes with a wide range of soils developed on drift deposits. Thus, patches of sandy soil of low zinc and other nutrient element status can often be found amongst more clay-rich soils with adequate levels of available micronutrients. Zinc total value may be very low in highly acidic soils due to the intense soil leaching (Brennan et al., 1993). N, P, K, S and $\mathrm{Cu}, \mathrm{Zn}$ and Mo deficiencies are common in many coarse textured, acid soils of Ethiopia. Zinc deficiency is widespread in Ethiopia's human and cattle populations that depend on teff, maize and 
straw, respectively, as major source of $\mathrm{Zn}$. Cereals $\mathrm{Zn}$ concentration has been reported to be low in Ethiopia. This could be partly due to low soil $\mathrm{Zn}$ supply (Melaku Umeta et al., 2003).

The means and ranges of concentrations of total zinc in the studied soil samples were found to be $50.49 \mathrm{mg} \mathrm{Kg}^{-1}$ (44.80-65.22 $\mathrm{mg} \mathrm{Kg}^{-1} \mathrm{DW}$ ), respectively. A critical value of $20 \mathrm{mg} \mathrm{Kg}^{-1}$ has been suggested as a general value for the interpretation of soil analyses. Thus, the total soil micronutrient concentration averages in this study were all in ranges that are considered normal for soil background concentrations. Similar total soil micronutrient concentrations compared well with the respective values reported from other countries are documented (Kabata-Pendias and

Table 1. Ranges and Means $(\mathrm{X} \pm \mathrm{SD}, \mathrm{n}=3)$ of Total Zinc Concentrations in Surface Soils $(0-20 \mathrm{~cm})$ from Central Mecha; 2010.

\begin{tabular}{llll}
\hline Study Kebeles & Number of Fields & $\begin{array}{l}\text { Range } \\
\left(\mathrm{mg} \mathrm{Zn} \mathrm{Kg}^{-1}\right)\end{array}$ & $\begin{array}{l}\text { Mean of Zn } \\
\left(\mathrm{mg} \mathrm{Kg}^{-1}\right)\end{array}$ \\
\hline Bachima & 6 & $55.29-65.22$ & $58.38 \pm 0.16$ \\
Ambomesk & 4 & $52.6-54.95$ & $54.05 \pm 0.01$ \\
Tagel Wodefit & 4 & $51.16-51.95$ & $51.68 \pm 0.02$ \\
Inguti & 4 & $50.17-50.47$ & $50.37 \pm 0.01$ \\
Enashenifalen & 4 & $48.53-48.93$ & $48.78 \pm 0.02$ \\
Enamirt & 4 & $46.22-47.95$ & $47.27 \pm 0.01$ \\
${ }^{*}$ Kudmi & 4 & $44.78-46.72$ & $45.55 \pm 0.01$ \\
\hline Total & $\mathbf{3 0}$ & $\mathbf{4 4 . 7 8 - 6 5 . 2 2}$ & $\mathbf{5 0 . 8 7}$ \\
\hline
\end{tabular}

"Zinc total level may be very low in highly acidic soils due to the intense soil leaching.

Table 2. Means and ranges of soils in Central Mecha Vis-à-Vis other soils in Ethiopia and around the world.

\begin{tabular}{lllll}
\hline Location & \multicolumn{1}{c}{$\begin{array}{c}\text { Soil type and } \\
\text { Climate }\end{array}$} & \multicolumn{1}{c}{$\begin{array}{c}\text { Range } \\
\left(\mathrm{mg} \mathrm{Zn} \mathrm{Kg}^{-1}\right)\end{array}$} & $\begin{array}{c}\text { Mean of } \\
\text { Zinc }\left(\mathrm{mg} \mathrm{Kg}^{-1}\right)\end{array}$ & \multicolumn{1}{c}{ Reference } \\
\hline France & Clay soils & - & $(98)$ & Alloway, B.J. \\
German & Clay soils & - & $(76.4)$ & Alloway, B.J. \\
Poland & Loess soils & $28-116$ & 60 & Kabata-Pendias et al. \\
USA & All types & - & 56.5 & Alloway, B. J. \\
India & Humid tropical soils & $22-74$ & 54 & Alloway, B. J. \\
Australia & Old Soils & $2-180$ & 34 & Alloway, B.J. \\
World & All types & $10-300$ & 50 & Alloway, B.J. \\
Mecha & Nitosols & $44.78-65.22$ & 50.87 & This study \\
\hline
\end{tabular}


Table 3. Ranges and Means $(\mathrm{X} \pm \mathrm{SD}, \mathrm{n}=3)$ of available Zinc Concentrations in surface Soils $(0-20 \mathrm{~cm})$ from Central Mecha; 2010.

\begin{tabular}{llll}
\hline Study Kebeles & Number of Fields & $\begin{array}{l}\text { Range } \\
(\mathrm{mg} \mathrm{Zn} \mathrm{Kg}\end{array}$ & $\begin{array}{l}\text { Mean of Zn } \\
\left(\mathrm{mg} \mathrm{Kg}^{-1}\right)\end{array}$ \\
\hline "Bachima & 6 & $1.94-3.01$ & $2.51 \pm 0.09$ \\
Tagel Wodefit & 4 & $2.26-3.24$ & $2.63 \pm 0.06$ \\
Enashenifalen & 4 & $1.79-3.19$ & $2.74 \pm 0.05$ \\
Ambomesk & 4 & $2.61-3.84$ & $3.06 \pm 0.05$ \\
Inguti & 4 & $2.66-4.45$ & $3.18 \pm 0.07$ \\
Enamirt & 4 & $2.29-4.06$ & $3.22 \pm 0.04$ \\
Kudmi & 4 & $2.37-4.94$ & $3.39 \pm 0.09$ \\
\hline Total & $\mathbf{3 0}$ & $\mathbf{1 . 7 9 - 4 . 9 4}$ & $\mathbf{2 . 9 6}$ \\
\hline
\end{tabular}

${ }^{*}$ Plant available Zinc level may be very low in soils with lower organic content and higher PH of the soil solution.

Pendias, 2001). Tables below (Table 1 and 2) show sufficient inherent total zinc concentrations in the soils of central Mecha.

The total $\mathrm{Zn}$ concentration are seldom used as a test for evaluating plant availability of soil $\mathrm{Zn}$ as the total $\mathrm{Zn}$ pool often incorporates $\mathrm{Zn}$ in unweathered minerals that is unavailable for plant growth. There has been a general trend towards the use of different soil test procedures which can be used for several micronutrients and also potentially toxic elements in one extraction to assess plant available micronutrients in soils. On a global scale, DTPA (Diethylene-triamine-penta-actetate), EDTA (Ethylene-diamine-tetra-acetate), hydrochloric acid, ammonium bicarbonate-DTPA and Mehlic test are relatively popular. The use of hydrochloric acid as extractant is used in here to determine plant available zinc concentrations in the soil samples as described by Brennan and others (Brennan et al., 1993). The mean and ranges of concentrations of available $\mathrm{HCl}$-extractable $\mathrm{Zn}$ in the studied soils were found to be $2.95 \mathrm{mg} \mathrm{Kg}^{-1}$ (1.76 to $4.94 \mathrm{mg}$ $\mathrm{Kg}^{-1} \mathrm{DW}$ ) (Table 3).

The concentrations of $0.1 \mathrm{M} \mathrm{HCl}$-extractable zinc used for interpreting soil analyses show levels of plant availability and zinc concentrations ( $\mathrm{mg} \mathrm{Zn}$ $\mathrm{Kg}^{-1}$ dry soil). According to Brennan and Srivastava (Brennan et al., 1993 and Srivastava et al., 1996), the concentrations of $0.1 \mathrm{M} \mathrm{HCl}$-extractable $\mathrm{Zn}$ of $1.6-3.0 \mathrm{mg} \mathrm{kg}^{-1}$ are considered medium as it is in between the critical levels for normal crop growth. Available $\mathrm{Zn}$ in the studied surface soils varied from 1.76 to $4.94 \mathrm{mg} \mathrm{kg}^{-1}$ with a mean value of $2.95 \mathrm{mg} \mathrm{kg}^{-1}$. Considering $0.8 \mathrm{mg} \mathrm{kg}^{-1}$ as the lower critical limit of available $\mathrm{Zn}$ as suggested by Brennan and Srivastava (Brennan et al., 1993 and Srivastava et al., 1996), the entire representative soils were under sufficient categories. The $0.1 \mathrm{M}$ $\mathrm{HCl}$ extractable zinc concentrations of studied soil samples were medium it in all instances. HCl-extractable soil metal concentrations were generally medium, as is to be expected for nitosol soils from young basaltic rock origin.

The critical concentrations for the interpretation of soil tests are often highly specific to certain types of soil and crops. It is therefore important for local expert advice to be sought in the interpretation of soil test results and the most appropriate method of treatment, if this is required. Quite often soil $\mathrm{pH}$, 
clay and organic matter contents will also be taken into consideration. The advantage of soil tests over plant analysis is that they enable possible deficiencies to be predicted in advance of growing the crop so that appropriate fertilisation or other treatments can be made to prevent the yield and/or quality of the future crop being impaired by zinc deficiency. The phytoavailability of soil micronutrients de- pends on soil properties such as total micronutrient concentrations, $\mathrm{pH}$, calcium carbonate $\left(\mathrm{CaCO}_{3}\right)$ content, organic matter $(\mathrm{OM})$ content, soil moisture conditions, and available phosphorus (Mahin et al., 2009). Available $\mathrm{Zn}$ showed significant correlation coefficient with $\mathrm{pH}, \mathrm{OC}$, available $\mathrm{N}$, and available $\mathrm{P}_{2} \mathrm{O}_{5}$. Low solubility of $\mathrm{Zn}$ in soils rather than low total amount of $\mathrm{Zn}$ is the major reason for

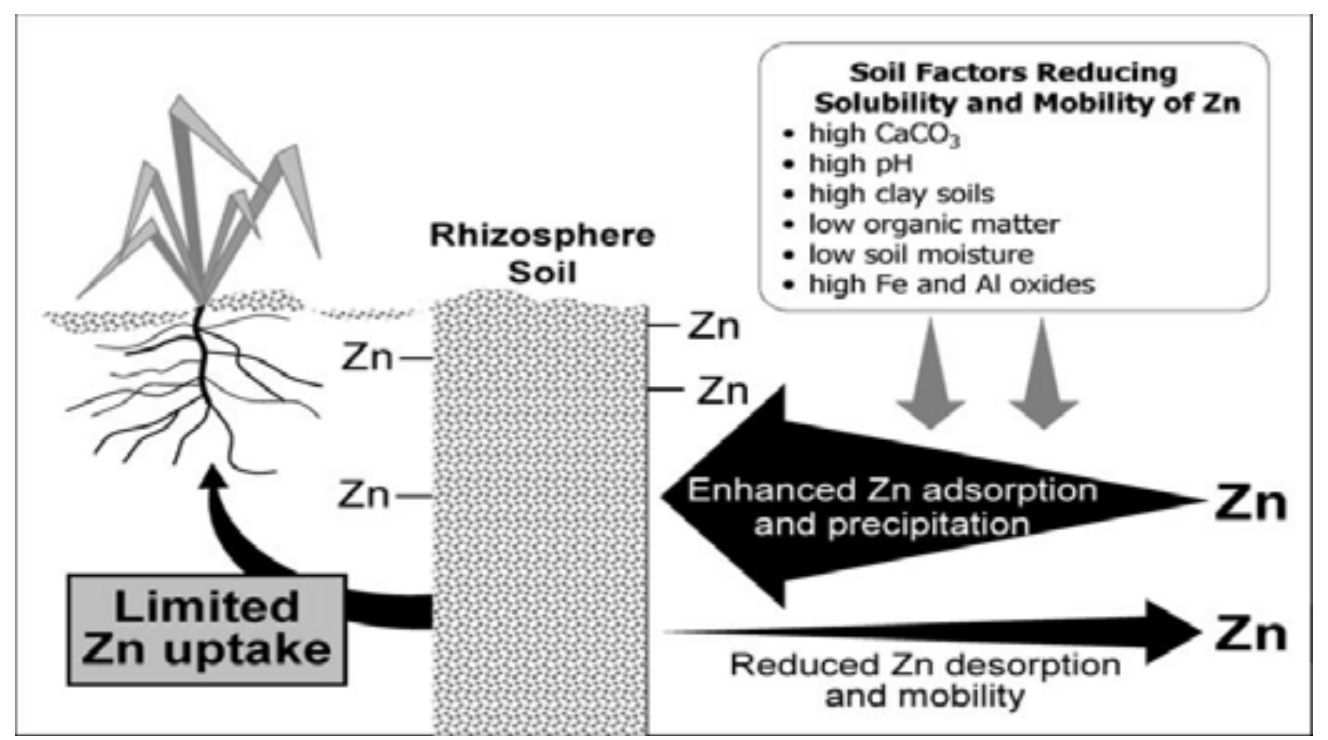

Figure 4. Major Soil Physical and Chemical Factors Affecting Availability of Zinc to Roots.

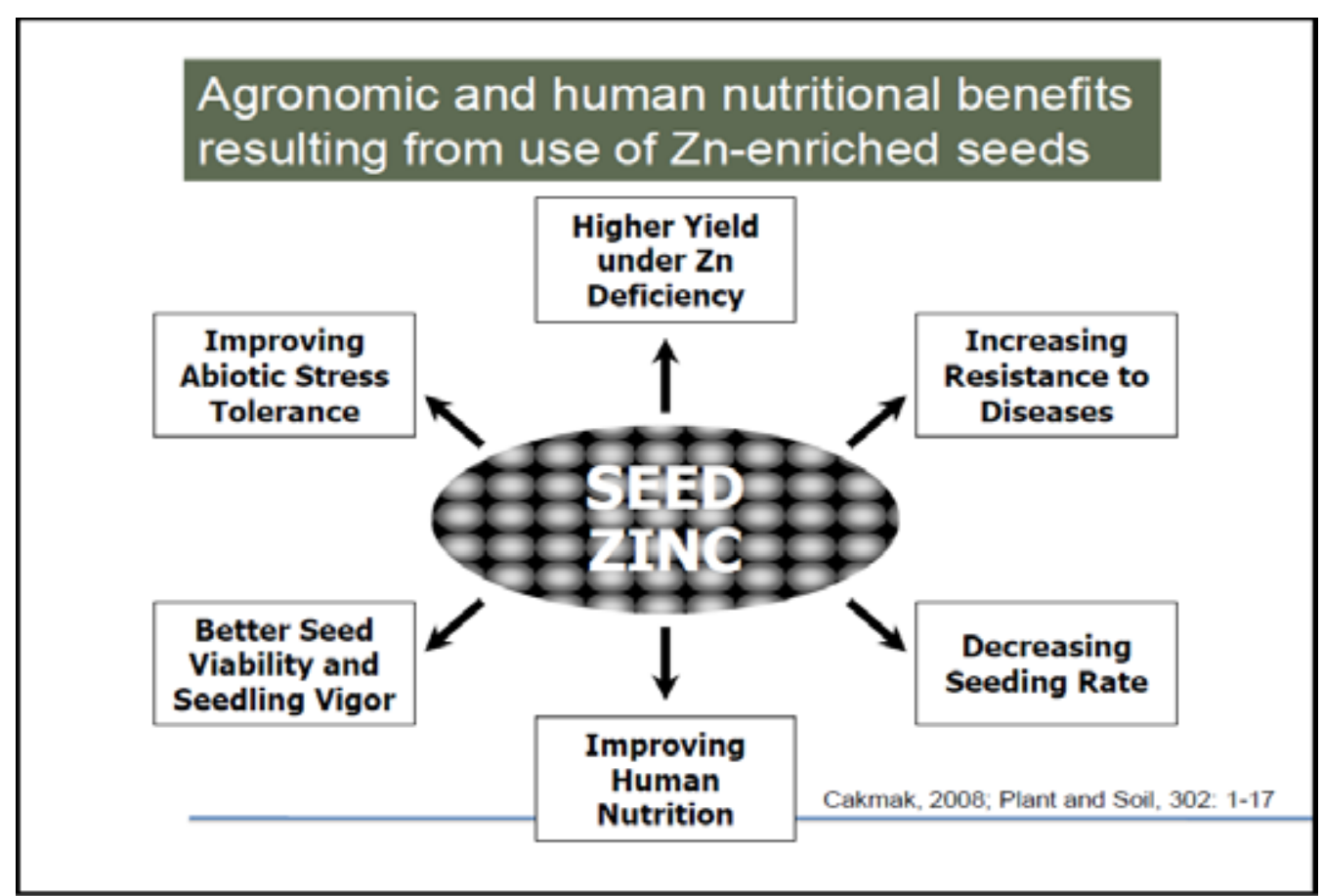

Figure 5. Agronomic and human nutritional Benefits from use of Zn-enriched seeds. 
the widespread occurrence of Zn deficiency problem in crop plants (Figures 4).

\section{Zinc Concentrations in Seeds of Maize}

The concentration of zinc in grain can also be used as a retrospective indication of the zinc status of the previous crop and in identifying areas where future grain crops could suffer from deficiency. A critical value of $15 \mathrm{mg} \mathrm{Zn} \mathrm{kg}^{-1}$ has been suggest- ed as a general value for the interpretation of grain analyses (Mahin et al., 2009; Ghulam et al., 2011). ANOVA revealed significant differences $(\mathrm{P}<0.05)$ between maize varieties in their zinc levels. There was significant genetic variability in the level of zinc between the maize cultivars from $16.18 \mathrm{mg}$ $\mathrm{Kg}^{-1}$ for BH-540; $20.08 \mathrm{mg} \mathrm{Kg}^{-1}$ for BH-660; 21.08 $\mathrm{mg} \mathrm{Kg}{ }^{-1}$ for Phb-3253; $23.26 \mathrm{mg} \mathrm{Kg}^{-1}$ for $\mathrm{BH}-543$; $29.38 \mathrm{mg} \mathrm{Kg}^{-1}$ for Melkassa-2 to $32.52 \mathrm{mg} \mathrm{kg}^{-1}$ for Melkassa-4 (Table 4 and 5).

Table 4. Ranges and means $(\mathrm{X} \pm \mathrm{SD}, \mathrm{n}=3)$ of levels of grain Zinc $\left(\mathrm{mg} \mathrm{Kg}{ }^{-1}\right)$ in six different tropical maize genotypes in Central Mecha; 2012.

\begin{tabular}{llll}
\hline Genotypes & Source & $\begin{array}{l}\text { Range } \\
\left(\mathrm{mg} \mathrm{Zn} \mathrm{Kg}^{-1}\right)\end{array}$ & $\begin{array}{l}\text { Mean of Zn } \\
\left(\mathrm{mg} \mathrm{Kg}^{-1}\right)\end{array}$ \\
\hline BH-540 & Bako NMR & $16.01-16.35$ & $16.18 \pm 0.13$ \\
BH-660 & Bako NMR & $20.00-20.16$ & $20.08 \pm 0.08$ \\
PhB-3253 & Pioneer & $21.08-21.13$ & $21.08 \pm 0.05$ \\
BH-543 & Bako NMR & $22.46-24.06$ & $23.26 \pm 0.80$ \\
Melkassa-2 & Melkassa & $28.14-30.62$ & $29.38 \pm 1.24$ \\
Melkassa-4 & Melkassa & $32.1-32.94$ & $32.52 \pm 0.42$
\end{tabular}

$\mathrm{NMR}=$ National Maize Research

Table 5. Range in concentrations of zinc $\left(\mathrm{mg} \mathrm{Kg}^{-1}\right)$ in maize and different crops.

\begin{tabular}{ccccc}
\hline Crop & Genotypes/Location & $\begin{array}{c}\text { Range of Zinc } \\
\left(\mathrm{mg} \mathrm{Kg}^{-1}\right)\end{array}$ & $\begin{array}{c}\text { Mean of Zn } \\
\left(\mathrm{mg} \mathrm{Kg}^{-1}\right)\end{array}$ & Reference \\
\hline Wheat & Wheat grains in Turkey & $23.25-41.76$ & 27.23 & Ali Riza D. \\
& Wheat grains in Ethiopia & $5.93-9.88$ & 7.905 & Zelalem T. \\
Maize & Corn grain in Turkey & $16.31-130.56$ & 35.06 & Ali Riza D. \\
& Corn grain in Mecha & $16.01-32.52$ & 23.7 & This study \\
\multirow{2}{*}{ Teff } & Red teff, Ethiopia & $23.0-67.0$ & 47.9 & Zeleke K. \\
& White teff, Ethiopia & $23.9-29.8$ & 29.8 & Zeleke K. \\
\multirow{2}{*}{ Gibto } & Gibito in Ethiopia & $40.3-53.6$ & 46.8 & Shimelis E. \\
Lentils & Lentils in Ethiopia & $86.2-100.3$ & 87.9 & Leshe S. \\
\hline
\end{tabular}


It has been indicated that micronutrient levels in maize grains were controlled to a large extent by environmental factors and interactions between the genotypes and the environment (Mahin et al., 2009; Ghulam et al., 2011). Based on a range of reports and this survey study, the average concentration of $\mathrm{Zn}$ in whole grain of Maize in various countries was between 16 to $35 \mathrm{mg} \mathrm{kg}^{-1}$ (Rengel et al., 1999; Cakmak et al., 2004). The Zn concentrations in cereals reported so far and found in this study were too low to meet daily human requirement, especially for those consuming a high proportion of cereal-based diets.

Recommended dietary allowance for zinc in infants (6 months-1year); 3-5 mg/day, children (1-10 yr); $10 \mathrm{mg} /$ day, adults; $15 \mathrm{mg} /$ day, pregnant women; $20 \mathrm{mg} /$ day, and lactating mother; $25 \mathrm{mg} /$ day. Generally, recommended dietary allowance for $\mathrm{Zn}$ is around $15 \mathrm{mg}$ per day (National Research Council, 1989). Fortification and supplementation are other strategies to combat zinc deficiency emergencies in risk populations. Zinc supplementation (Lemelem plus oral rehydration salt provision) during diarrhoea has lowered morbidity and mortality in children. Zinc deficient infants showed improvements in growth rate and a reduced incidence of acute lower respiratory infection after zinc supplementation. Chronic ingestion of zinc supplements exceeding $15 \mathrm{mg} /$ day is not recommended without adequate medical supervision

For a measurable biological impact on human health, the concentration of $\mathrm{Zn}$ in whole maize grain needs to be increased at least by approximately $10 \mathrm{mg} \mathrm{kg}^{-1}$, assuming a $400 \mathrm{~g}$ per day intake for adult woman in the countries where whole grain flour is used for making food (Pfeiffer and McClafferty, 2007). Thus, there is increasing interest in the zinc concentration (density) in grains used for human consumption. The aim will be to increase the zinc concentration in grain to $40-60$ mg Zn kg-1 which is much higher than the concentration indicating possible yield losses due to zinc deficiency. This can be achieved by either genetic or agronomic biofortification. The use of improved varieties and or application of fertilizers blended with zinc compounds can be used for optimal results. However, it is also important to note that future experimental research on the amount of zinc required for alleviating zinc deficiency should consider severity of deficiency, soil types, nature of crops and cultivars. In majority of instances of Zinc deficiency in the soils can be best alleviated with the use of 5-11 $\mathrm{kg} \mathrm{Zn} \mathrm{ha}^{-1}$ to wheat, rice and maize agricultural farms.

\section{CONCLUSIONS}

The chemical analysis of composite soil samples in central Mecha Kebeles in the south west maize livelihood zone in Amhara region indicated that $\mathrm{Zn}$ in the soil is sufficient to support good crop growth for now, however; the variations in the level of zinc among the different maize cultivars should be significant in limiting high and quality yield for consumption than inherent zinc deficiency in the soils. The use of speciality fertilizers which contain zinc and use of zinc efficient crop varieties may give positive responses if other limiting factors such as low organic matter, high phosphorus fixing capacity and acidity of the soils are also concurrently managed. Generally future work in this area should focus on better understanding of the biogeochemical processes that control trace element cycling and comprehensive dataset on the abundance of trace elements in abiotic and biotic environmental compartments to better manage trace elements in the environment which is a prerequisite to sustain land use and, presumably, to increase product yield and quality in agriculture and diminish health risks due to deficiency or toxicity of micronutrients in the biosphere. 


\section{ACKNOWLEDGEMENTS}

The authors acknowledge Bahir Dar University for financial support and Amhara Design and Construction Enterprise for giving their support in conducting the laboratory analyses.

\section{REFERENCES}

Afework Kassu, Tomoki Yabutani, Andargachew Mulu, Belay Tessema and Fusao Ota. (2008). Serum Zinc, Copper, Selenium, Calcium, and Magnesium Levels in Pregnant and NonPregnant Women in Gondar, Northwest Ethiopia. Biological Trace Elements Research 122:97 106.

Ashenafi Ali., Abayneh Esayas and Sheleme Beyene. (2010). Characterizing soils of Delbo Wegene watershed, wolaita Zone, Southern Ethiopia for planning appropriate land management. Journal of Soil Science and Environment Management 1(8):184 - 199.

Ali, R.D. (2009). Determination of $\mathrm{Fe}, \mathrm{Cu}$ and $\mathrm{Zn}$ contents of wheat and corn grains from different growing site. Journal of Animal and Veterinary Advances 8(8): 1563 - 1567.

Alloway, B.J. (2004). Zinc in soils and crop nutrition, pp1-116, International Zinc Association, Brussels.

Asgelil Dibabae, Taye Bekele and Yesuf Assen. (2007). The status of micronutrients in Nitisols, Vertisols, Cambisols and Fluvisols in major maize, wheat, teff and citrus growing areas of Ethiopia. In Proceedings of Agricultural Research Fund pp. 77 - 96, EIAE, Addis Ababa, Ethiopia.

Brennan, R.F., Armour, J. D and Reuter, D. J. (1993). Diagnosis of zinc deficiency, Chap 12 In: Zinc in Soils and Plants, pp 206 (Robson, A.D. (ed)), Kluwer Academic Publishers, Dordrecht.

Cakmak, İ., Torun, A., Millet, E., Feldman, M., Fahima, T., Korol, A and Özkan, H. (2004). Triticum dicoccoides: an important genetic resource for increasing zinc and iron concentration in modern cultivated wheat. Soil Science and Plant Nutrition 50 (7):1047 - 1054.

Cakmak, I. (2008). Enrichment of cereal grains with $\mathrm{Zn}$ : Agronomic or genetic biofortification? Plant Soil 302:1 - 17.

Cakmak, I. (2008). Zinc deficiency in wheat in Turkey. Chap. 7 In: Micronutrient deficiency in global crop production, (Alloway, B. J. (ed.), Springer, Dordrecht.

Ethiopian Agricultural Transformation Agency (ATA) (2013). The status of soil resources in Ethiopia and priorities for sustainable management, GSP for Eastern and South Africa. March 25 - 24, 2013, Nairobi, Kenya.

Ghulam, Q. S., Tasneem, G. K., Farman, A. S and Abdul, H. S. (2011). Variable uptake and accumulation of essential and heavy metals in Maize (Zea mays L.) grains of six Maize varieties. Australian Journal of Basic and Applied Sciences 5(2):117 - 121.

Hotz, C and Brown, K.H. (2004). Assessment of the risk of zinc deficiency in populations and options for its control. Food and Nutrition Bulletin 25:94 $-204$.

Jemal Haidar, Melaku Umeta and Kogi-Makasu, W. (2005). Effect of iron supplementation on serum zinc status of lactating women in Addis Ababa, Ethiopia. East African Medical Journal 82(7): 349 - 52.

Kabata-Pendias, A and Pendias, H. (2001). Trace Elements in Soils and Plants, 3rd ed.; CRC Press; Boca Raton, FL. 
Lindsay, W. L and Norvell, W. A. (1978). Development of a DTPA soil test for zinc, iron, manganese, and copper. Soil Science Society. of American Journal 42:421 - 428.

Mahin K., Majid A., Amir H. K., Adreas P and Rainer S. (2009). Grain Zinc, Iron, and Copper Concentrations of Wheat Grown in Central Iran and Their Relationships with Soil and Climate Variables. Journal of Agriculture and Food Chemistry 57:10876 - 10882.

Mclean, K. S and Langille, W. M. (1976). Studies in soil copper I: Factors affecting copper extractability. Communication in Soil Science and Plant Analysis 7:771 - 785.

Melaku Umeta. (2003). Role of Zinc in Stunting of Infants and Children in Rural Ethiopia. M Sc Dissertation, Wageningen University, Netherlands.

Melaku Umeta, West, C. E., Verhoef, H., Jemal Haidar and Hautvast, J. G. (2003). Factors Associated with Stunting in Infants Aged 5-11 Months in the Dodota-Sire District, Rural Ethiopia. Journal of Nutrition 133(4):1064 1069.

Minaleshewa Atlabachew, Chandravanshi B. S and Mesfin Redi. (2010). Concentration levels of essential and non-essential metals in Ethiopian Khat (Catha edulis Forsk). Biological Trace Elements Research 138:316 - 325.

Pfeiffer, W. H and McClafferty, B. (2007). HarvestPlus: breeding crops for better nutrition. Crop Science 47(Supplement_3): S-88.

Rengel, Z., Butlen G. D and Crowley D. E. (1999). Agronomic approaches for improving micronutrient density. Field Crops Research 60:27 - 40 .
Samson Gebremedhin, Fikre Enquselassie and Melaku Umeta. (2011). Prevalence of prenatal zinc deficiency and its association with sociodemographic, dietary and health care related factors in Rural Sidama, Southern Ethiopia: A cross-sectional study. BMC Public Health 11:898 - 907.

Sintayehu Leshe. (2010). Determination of the levels of trace metals in Ethiopian Lentils (Lens Culinaris Medik). M. Sc. Thesis, Addis Ababa University, Addis Ababa, Ethiopia.

Sillanpaa, M. (1990). Micronutrient assessment at the country level. An international study, FAO Soil Bulletin 63; FAO, Rome.

Shittu, O. S. (2008). Evaluation of four selected micronutrients in soils developed over Charnockite in Ekite State. PhD Thesis, Ekiti State University, Ado Ekiti, Nigeria.

Shittu, O. S. (2013). Hydrochloric (0.1M) and DTPA-extractable and total zinc in Charnockite soil profile of Ekite State, Nigeria. Elixir Agriculture 55:13010 - 13012.

Srivastava, P.C and Gupta U. C. (1996). Trace Elements in Crop Production. Science Publishers, Lebanon, New Hampshire.

Tayie, F. A., Koduah, G and Sap Mork. (2013). Geophagia clay soil as a source of mineral nutreients and toxicants. African Journal of Food Agriculture Nutrition and Development 13(1):7157 - 7170 .

Teklu Baissa, Suwanarit, A., Osotsapar, Y and Sarobo, E. D. (2005). The status of $\mathrm{B}, \mathrm{Cu}$, $\mathrm{Fe}, \mathrm{Mo}$, and $\mathrm{Zn}$ of soils of Ethiopia for maize production: Greenhouse Assessment. Kasetsart Journal (Natural Sciences) 39:357 - 367. 
Teklu Baissa, Suwanarit, A., Osotsapar, Y and Sarobo, E.D. (2007). The status of $\mathrm{Mn}, \mathrm{Fe}$, $\mathrm{Cu}, \mathrm{Zn}$, and B in Rift Valley soils of Ethiopia: Laboratory Assessment. Kasetsart Journal (Natural Sciences) 41:84 - 95.

Tizazu Mekonnen and Shimelis Emire. (2010). Chemical composition, physicochemical and functional properties of lupin (Lupinus albus) seeds grown in Ethiopia. African Journal of Food Agriculture Nutrition and Development 10 (8):3029 - 3046.

Tuma Ayele, Mekonnen Ayana, Tesema Tanto and Degife Asefa. (2014). Evaluating the status of micronutrients under irrigated and rain-fed agricultural soils in Abaya Chamo lake basin south-west Ethiopia. Journal of Scientific Research and Reviews 3(1):18 - 29.

Van Reeuwijk, L. P. (1993). Procedures for soil analysis, ( $4^{\text {th }}$ ed.). International soil reference and Information centre (ISRIC), Wageningen, the Netherlands.

Walkey, A and Black, I. A. (1934). An examination of the Degtjareff method for determining soil organic matter and proposed modification of the chromic acid titration method. Soil Science. 37: $29-38$.

Welch, R. M., Allaway, W. H., House, W. A and Kubota, J. (1991). Geographic distribution of trace element problems: Micronutrients in Agriculture. 2nd ed.; SSSA Book Series, Madison.

Welch, R. M and Grahamand R. D. (2002). Breeding crops for enhanced micronutrient content. Plant Soil 245:205 - 214.

World Health Organization. (2002). The World Health Report, Geneva.
Yang, X. E., Chen, W. R and Feng, Y. (2007). Improving human micronutrient nutrition through biofortification in the soil-plant system: China as a case study. Environmental Geochemistry and Health 29:413 - 428.

Yehenew Gebreselassie. (2002). Selected Chemical and Physical characteristics of Soils of Adet Research Centre and its Testing Sites in North Western Ethiopia. Ethiopian Journal of Natural Resources 2002, 4 (2):199 - 215.

Yifru Abera and Mesfin Kebede. (2013). Assessment on the status of some micronutrients in Vertisols of the central highlands of Ethiopia. International Research Journal of Agricultural Science and Soil Science 3(8):169 - 173.

Zelalem Tadesse. (2006). Levels of trace cadmium and essential zinc in wheat flour commercially available in Addis Ababa, Ethiopia. M.Sc. Thesis, Addis Ababa University, Ethiopia

Zeleke Kebede. (2009). Levels of essential elements in three Teff Varities. M.Sc. Thesis, Addis Ababa University, Ethiopia. 